\title{
Hubungan Tingkat Thyroid Stimulating Hormone dengan Fungsi Kognitif
}

\section{Relationship of Thyroid Stimulating Hormone Levels with Cognitive Function}

\author{
Dira Wahyuni $S^{1,2}$, Fasihah Irfani $F^{1,2}$, Iskandar Nasution ${ }^{1,2}$, Rusli Dhanu ${ }^{1,2}$ \\ ${ }^{1}$ Departemen Neurologi Fakultas Kedokteran Universitas Sumatera Utara Medan \\ ${ }^{2}$ Rumah Sakit Umum Pusat H Adam Malik Medan
}

\begin{abstract}
ABSTRAK
Gangguan hormon tiroid merupakan salah satu gangguan endokrin yang utama mewakili 30\% hingga 40\% dari pasien yang datang dalam praktek endokrin. Gangguan hormon tiroid merupakan salah satu penyebab gangguan fungsi kognitif. Tujuan dari penelitian ini untuk mengetahui adanya hubungan tingkat TSH dengan fungsi kognitif pasien dengan gangguan fungsi tiroid. Penelitian ini merupakan studi analitik dengan desain potong lintang, pada pasien dengan gangguan fungsi tiroid yang berobat di Poliklinik Endokrin RSUP Haji Adam Malik Medan. Tingkat TSH dikelompokkan sebagai tinggi $(>4,67 \mu \mathrm{lU} / \mathrm{ml})$, normal $(0,49-4,67 \mu \mathrm{lU} / \mathrm{ml})$ dan rendah $(<0,49 \mu \mathrm{lU} / \mathrm{ml})$. Fungsi kognitif dinilai dengan menggunakan Montreal Cognitive Assessment-Versi Indonesia (MoCA-INA) dengan nilai normal 26-30. Pada penelitian ini melibatkan 55 pasien yang terdiri dari 11 pasien laki-laki (20\%) dan 44 pasien perempuan (80\%). Rerata usia adalah 41,69 $\pm 11,50$ tahun. Terdapat 13 pasien tingkat TSH tinggi (23,6\%), 15 pasien tingkat TSH normal (27,3\%) dan 27 pasien tingkat TSH rendah (49,1\%). Nilai median MoCA-INA adalah 24(9-30). Hasil uji Kruskal-Wallis menunjukkan hubungan yang signifikan antara tingkat TSH dengan fungsi kognitif $(p=0,017)$.
\end{abstract}

Kata Kunci: Fungsi kognitif, hormon tiroid, Thyroid Stimulating Hormone

\section{ABSTRACT}

Thyroid hormone disorder is one of the main endocrine disorders and represents around $30 \%$ to $40 \%$ of patients who come to endocrine practice. This disorder is one of the causes of cognitive function disorders. This study aimed to determine the relationship between TSH level and cognitive function of patients with thyroid dysfunction. This research was an analytic study with cross-sectional design among patients with thyroid function disorders who sought treatment at the Endocrine Polyclinic of Haji Adam Malik Geneal Hospital Medan. TSH levels were identified as high (> 4.67 $\mu \mathrm{l} / \mathrm{ml})$, normal (0.49-4.67 $\mu \mathrm{IU} / \mathrm{ml})$ and low $(<0.49 \mu \mathrm{IU} / \mathrm{ml})$. The cognitive function was assessed using the Montreal Cognitive Assessment-Indonesian Version (MoCA-INA) with a normal score of 26-30. The research involved 55 patients consisting of 11 men (20\%) and 44 women (80\%). The average age of the patients was $41.69 \pm 11.50$ years. There were 13 patients with high TSH level (23.6\%), 15 patients with normal TSH level (27.3\%), and 27 patients with low TSH level (49.1\%). The median value of MoCAINA was 24(9-30). The Kruskal-Wallis test results showed a significant relationship between TSH level and cognitive function $(p=0.017)$.

Keywords: Cognitive function, thyroid hormone, Thyroid Stimulating Hormone

Korespondensi: Dira Wahyuni S. Departemen Neurologi Fakultas Kedokteran Universitas Sumatera Utara Medan, Jl. Dr. Mansyur No.5, Padang Bulan, Kec. Medan Baru, Kota Medan, Sumatera Utara 20155 Tel.081360712282 Email: dira.siregar@gmail.com

DOI: http://dx.doi.org/10.21776/ub.jkb.2019.030.04.11 


\section{PENDAHULUAN}

Gangguan hormone tiroid merupakan salah satu gangguan endokrin utama yang menggambarkan $30 \%$ hingga $40 \%$ dari pasien yang datang dalam praktek endokrin (1). Semakin banyak bukti yang menghubungkan perubahan dalam sistem endokrin dengan patogenesis Alzheimer's Disase dan demensia lainnya. Gangguan hormon tiroid merupakan salah satu penyebab gangguan fungsi kognitif. Pemeriksaan kadar thyroid stimulating hormone (TSH) dianjurkan sebagai bagian dari evaluasi pasien demensia (2). Gangguan kognitif dan demensia meningkat secara global dan diprediksi akan meningkat secara proporsional lebih banyak di negara-negara berkembang. Data menunjukkan bahwa pada tahun 2050 jumlah orang pada usia $>60$ tahun akan menjadi sekitar 2 miliar dan akan mencakup $22 \%$ dari populasi dunia. Diperkirakan 35,6 juta orang saat ini hidup dengan demensia di seluruh dunia dan jumlahnya akan hampir berlipat ganda setiap 20 tahun, mencapai 115,4 juta pada 2050, dengan mayoritas yang tinggal di negara berkembang. Data pada tahun 2010 menunjukkan bahwa dari jumlah total orang dengan demensia di seluruh dunia, $57,7 \%$ tinggal di negara-negara berkembang dan diprediksi terjadi peningkatan menjadi $70,5 \%$ pada tahun 2050 (3).

Thyroid Stimulating Hormone (TSH) merupakan marker yang sensitif untuk menilai fungsi tiroid yang abnormal, sehingga sebagian besar penelitian menggunakan TSH sebagai parameter (4). Berdasarkan fungsi, TSH paling relevan dalam fisiologi kelenjar tiroid, dimana hormon tiroid terlibat secara jelas dalam perkembangan dan fungsi sistem saraf pusat. Kekurangan atau kelebihan hormon tiroid pada individu dapat menyebabkan berbagai manifestasi klinis, termasuk gejala neurologis dan psikiatri (5). Oleh karena itu kadar TSH berpotensi sebagai penanda untuk evaluasi gangguan kognitif karena gangguan tiroid salah satu penyebab gangguan kognitif. Penelitian ini bertujuan untuk mengetahui adanya hubungan antara tingkat TSH dengan fungsi kognitif pada pasien gangguan troid di Poliklinik Endokrin RSUP. Haji Adaam Malik Medan.

\section{METODE}

Penelitian ini adalah studi analitik dengan desain potong lintang pada seluruh pasien gangguan tiroid di Poliklinik Endokrin RSUP. Haji Adam Malik Medan selama periode studi Agustus 2018-Januari 2019. Metode pengambilan sampel yaitu sampling non random secara konsekutif, data populasi yang memenuhi kriteria inklusi dan eksklusi yang telah disesuaikan dengan kebutuhan penelitian diambil sebagai sampel. Kriteria inklusi yang digunakan meliputi pasien gangguan tiroid yang belum pernah minum obat tiroid di Poliklinik Endokrin RSUP. Haji Adam Malik, compos mentis, usia 18-59 tahun, dapat membaca dan menulis, dapat berbahasa Indonesia dan memberikan persetujuan untuk ikut serta dalam penelitian ini. Pasien dengan stroke iskemik, hemoragik, tumor otak, chronic kidney disease, epilepsi, trauma kapitis, afasia, dan demensia dimasukkan kedalam kriteria eksklusi. Variabel bebas pada penelitian ini adalah tingkat TSH dan variabel terikat adalah fungsi kognitif dari pemeriksaan neurokognisi Montreal Cognitive Assessment-Versi Indonesia (MoCA-INA).
Dari penelitian ini didapatkan 55 pasien memenuhi kriteria inklusi dan eksklusi. Disamping data fungsi kognitif dan TSH juga dikumpulkan data karakteristik pasien meliputi usia, jenis kelamin, dan pendidikan. Usia pasien disajikan sebagai variabel rasio, jenis kelamin dan tingkat pendidikan disajikan sebagai variabel nominal. Tingkat TSH disajikan sebagai variabel ordinal, dikelompokkan berdasarkan nilai normal thyroid stimulating hormone menjadi 3 kelompok, yaitu tingkat TSH tinggi $(>4,67 \mu \mathrm{lU} / \mathrm{ml})$, normal $(0,49-4,67 \mu \mathrm{lU} / \mathrm{ml})$ dan rendah $(<0,49 \mu \mathrm{IU} / \mathrm{ml})$ dan skor MoCA-INA disajikan sebagai variabel rasio. Hubungan antara tingkat TSH dengan fungsi kognitif dianalisis menggunakan uji komparatif KruskalWallis dengan Windows SPSS (Statistical Product and Science Service) versi 22. Hubungan antara kedua variabel dikatakan signifikan apabila nilai $p<0,05$.

\section{HASIL}

Distribusi karakteristik sampel (Tabel 1) menunjukkan rerata usia pasien adalah $41,69 \pm 11,50$ tahun, sebagian besar perempuan $(44,80 \%)$ dengan tingkat pendidikan hingga SMA (63,9\%). Sebagian besar $(27,49,1 \%)$ pasien menunjukkan tingkat TSH rendah. Nilai median fungsi kognitif pasien berdasar skor MoCA-INA adalah 24 dengan nilai terendah 9 dan tertinggi 30 (semakin nilai MoCA-INA tinggi,semakin bagus fungsi kognitif, nilai 30 adalah nilai maksimum dari skor MoCA-INA).

Tabel 1. Karakteristik demografi subjek penelitian

\begin{tabular}{lrr}
\hline Deskripsi & $\mathbf{n}=\mathbf{5 5}$ & $\%$ \\
\hline Usia (tahun), Rerata \pm SD & $41,69 \pm 11,50$ & \\
Jenis Kelamin & & \\
Laki-laki & 11 & $20 \%$ \\
Perempuan & 44 & $80 \%$ \\
Pendidikan & & \\
SD & 4 & $7,3 \%$ \\
SLTP & 18 & $32,7 \%$ \\
SLTA & 17 & $30,9 \%$ \\
Perguruan Tinggi & 16 & $29,1 \%$ \\
Tingkat TSH & & \\
Tinggi $(>4,67 \mu \mathrm{IU} / \mathrm{ml})$ & 13 & $23,6 \%$ \\
Normal $(0,49-4,67 \mu \mathrm{IU} / \mathrm{ml})$ & 15 & $27,3 \%$ \\
Rendah $(<0,49 \mu \mathrm{IU} / \mathrm{ml})$ & 27 & $49,1 \%$ \\
MoCA-INA, Median (min-max) & $24(9-30)$ & \\
\hline
\end{tabular}

Hasil uji komparatif (Tabel 2) menunjukkan adanya hubungan signifikan $(p=0,017)$ antara hubungan tingkat TSH dengan fungsi kognitif pada pasien gangguan tiroid di Poliklinik Endokrin RSUP Haji Adam Malik Medan. Pasien dengan tingkat TSH normal cenderung mempunyai fungsi kognitif yang lebih tinggi bila dibandingkan kondisi kekurangan maupun kelebihan TSH.

Tabel 2. Hasil uji komparatif Kruskal-Wallis tingkat TSH dengan fungsi kognitif

\begin{tabular}{llrl}
\hline Tingkat TSH & $\mathbf{n}$ & $\begin{array}{r}\text { Skor MoCA-INA } \\
\text { Median (min-max) }\end{array}$ & $\mathbf{p}$ \\
\hline Tinggi & 13 & $21(13-27)$ & \\
Normal & 15 & $26(18-30)$ & 0,017 \\
Rendah & 27 & $23(9-27)$ & \\
\hline
\end{tabular}




\section{DISKUSI}

Pada penelitian ini, data menunjukkan rerata usia pasien adalah $41,69 \pm 11,50$ tahun. Penelitian sebelumnya pasien hipertiroid mempunai rentang usia $\mathrm{Hal}$ ini sesuai dengan pada penelitian tahun 2009 dan 2012 ditemukan rerata usia pasien hipertiroid adalah $40,9 \pm 11$ dan $41 \pm 10,6$ tahun $(6,7)$. Kajian pada pasien hipotiroid menemukan rentang usia antara 36 $\pm 9,2$ hingga 44 $\pm 10,9$ tahun (8-10). Usia yang semakin tua meningkatkan penurunan alami dalam sekresi TSH hipofisis dan deiodinasi T4, sementara terjadi peningkatan antibodi antitiroglobulin dan antitiroperoxidase. Ketika usia semakin bertambah, fungsi reproduksi, hormon seksual, dan hormon steroid menurun secara signifikan (11).

Sebagian besar subjek penelitian adalah perempuan 44 (80\%). Penelitian sebelumnya juga menemukan prosentase serupa atau rasio perempuan 2 kali lebih banyak dibandingkan laki-laki $(6,7)$. Hormon tiroid secara sistemik berperan dalam mengontrol metabolisme. Dimana fungsi kelenjar tiroid berada di bawah kendali hyprothalamo-pituitary axis, sehingga jika terjadi perubahan fungsi tiroid dapat berdampak besar pada fungsi reproduksi sebelum, selama dan setelah pembuahan. Penyakit tiroid adalah kondisi endokrin yang paling umum yang mempengaruhi wanita usia reproduksi (12).

Sebagain besar subjek penelitian mempunyai tingkat pendidikan hingga SMA, sejalan dengan penelitian sebelumnya yang menemukan tingkat pendidikan terbanyak SMA (6). Studi sebelumnya juga menemukan hubungan yang signifikan antara pendidikan terhadap fungsi kognitif pada pasien gangguan tiroid khususnya hipertiroid bila dinilai dari lama pendidikan sekolah dan hasil pemeriksaan neuropsikologi. Individu yang sudah belajar dengan jangka waktu yang lebih lama mempunyai skor neuropsikologi yang jauh lebih baik. Pendidikan yang lebih tinggi meningkatkan aktivitas intelektual yang lebih tinggi dengan beberapa peran protektif yang berkaitan dengan fungsi lobus frontal (7).

Hasil penelitian menemukan adanya hubungan yang signifikan tingkat TSH dengan fungsi kognitif pada pasien gangguan tiroid di Poliklinik Endokrin RSUP Haji Adam

\section{DAFTAR PUSTAKA}

1. Madariaga AG, Palacios SS, Guillén-grima $F$, and Galofré JC. The Incidence and Prevalence Of Thyroid Dysfunction In Europe: A Meta-Analysis. The Journal of Clinical Endocrinology and Metabolism. 2014; 99(3): 923-931.

2. Tan ZS, Beiser A, Vasan RS, et al. Thyroid Function and the Risk of Alzheimer's Disease: The Framingham Study. Archives of Internal Medicine. 2008; 168(14): 1514-1520.

3. Mavrodaris A, Powell J, and Thorogood M. Prevalences of Dementia and Cognitive Impairment among Older People in Sub-Saharan Africa: A Systematic Review. Bulletin of the World Health Organization. 2013; 91(10): 773-783.

4. Kim JM, Stewart R, Kim SY, et al. Thyroid Stimulating Hormone, Cognitive Impairment and Depression in an Older Korean Population. Psychiatry
Malik Medan $(p=0,017)$. Hal yang sama ditemukan pada beberapa penelitian sebelumnnya (2,13-15). Kadar TSH ditemukan berhubungan dengan risiko Alzheimer's Disease dan demensia $(2,13,14)$. Studi lain menunjukkan pasien hipertiroid subklinis lebih mungkin terjadi gangguan fungsi kognitif (hazard rate $=2,26, p=0,003$ ) (15). Beberapa penelitian eksperimental pada hewan mendukung pengamatan klinis terhadap pentingnya hormon tiroid untuk fungsi sistem saraf pusat. Hormon tiroid sangat penting untuk perkembangan struktural dan fungsional otak, termasuk area yang mengontrol proses afektif dan kognitif. Studi eksperimental pada hewan menunjukkan bahwa fungsi tiroid yang abnormal mengubah morfologi otak dan area yang mendukung fungsi kognisi. Hipotiroid onset dewasa pada tikus menunjukkan jumlah sel granula berkurang pada dentate gyrus dan sel piramidal pada area CA1 hipokampus serta menurunkan densitas tulang belakang dendritik apikal neuron piramidal CA1 hipokampus, dan plastisitas sinapsis hipocampus dan merusak proses belajar. Disfungsi tiroid juga mengubah ekspresi neurotransmiter, neuromodulator, dan sistem faktor pertumbuhan di otak tikus dewasa. Secara tidak langsung disfungsi tiroid mempengaruhi fungsi otak, termasuk area yang berperan pada afektif dan fungsi kognitif. Sebagai contoh defisiensi hormon tiroid mengubah ekspresi enzim hipocampus yang mengatur katekolamin, serotonin dan Gama Aminobutyric Acid (16).

Penelitian ini membuktikan bahwa level TSH berhubungan dengan fungsi kognitif pada pasien gangguan tiroid yang sebagian besar berusia lebih dari 40 tahun dan berjenis kelamin perempuan. Penelitian lebih lanjut dengan studi kohort perlu dilakukan untuk mengetahui perubahan fungsi kognitif setelah pemberian obat hormon tiroid serta melakukan pemeriksaan neuroimaging untuk menilai anatomi fungsi kognitif.

\section{UCAPAN TERIMA KASIH}

Peneliti mengucapkan terima kasih kepada Fakultas Kedokteran Universitas Sumatera Utara, Departemen Neurologi, dan Penyakit Dalam subdivisi Endokrin serta RSUP. Haji Adam Malik Medan yang telah memfasilitasi penelitian ini.

Investigation. 2010; 7(4): 264-269.

5. Bernal J. Action of Thyroid Hormone in Brain. Journal of Endocrinological Investigation. 2002; (3): 268-288.

6. Hia B, Dahlan P, and Ghofir A. Correlation Between Overt Hyperthyroid and Subclinical Hyperthyroid and Cognitive Impairment in Dr. Sardjito General Hospital, Yogyakarta, Indonesia. Journal Medicine Science. 2012; 44(1): 57-64.

7. Jabłkowska K, Karbownik-lewińska M, Nowakowska $\mathrm{K}$, Junik R, Lewiński A, and Borkowska A. Working Memory and Executive Functions in Hyperthyroid Patients with Graves' Disease. Psychiatria Polska. 2008; 42(2): 249-259.

8. Burmeister LA, Ganguli M, Dodge HH, Toczek T, Dekosky ST, and Nebes RD. Hypothyroidism and Cognition: Preliminary Evidence for a Specific Defect in Memory. Thyroid: Official Journal of the American Thyroid Association. 2001; 11(12): 1177-1185. 
9. Miller KJ, Parsons TD, Whybrow PC, et al. Verbal Memory Retrieval Deficits Associated with Untreated Hypothyroidism. The Journal of Neuropsychiatry and Clinical Neurosciences. 2007; 19(2): 132-136.

10. Correia N, Mullally S, Cooke G, et al. Evidence for a Specific Defect in Hippocampal Memory in Overt and Subclinical Hypothyroidism. The Journal of Clinical Endocrinology and Metabolism. 2009; 94(10): 37893797.

11. Bensenor IM, Olmos RD, and Lotufo PA. Hypothyroidism in the Elderly: Diagnosis and Management. Clinical Interventions in Aging. 2012; 7: 97-111.

12. Jefferys A, Vanderpump M, and Yasmin E. Thyroid Dysfunction and Reproductive Health. The Obstetrician and Gynaecologist. 2015; 17(1): 39-45.
13. Ganguli M, Burmeister LA, Seaberg EC, Belle S, and DeKosky ST. Association between Dementia and Elevated TSH: A Community-Based Study. Biological Psychiatry. 1996; 40(8): 714-725.

14. van Osch LADM, Hogervorst $E$, Combrinck $M$, and Smith AD. Low Thyroid Stimulating Hormone as an Independent Risk Factor for Alzheimer Disease. 2004; 62(11): 1967-1971.

15. Ceresini G, Lauretani ÃF, Maggio M, et al. Thyroid Function Abnormalities and Cognitive Impairment in Elderly People: Results of The Invecchiare in Chianti Study. Journal of the American Geriatrics Society. 2009; 57(1): 89-93.

16. Samuels MH. Thyroid Disease and Cognition. Endocrinology and Metabolism Clinics of North America. 2014; 43(2): 529-543. 